\title{
PROMETHEE-GAIA Method as a Support of the Decision-Making Process in Evaluating Technical Facilities
}

\author{
Alena Kocmanová, Marie Dočekalová, and Jiří Luňáček \\ Brno University of Technology, Faculty of Business and Management, \\ Kolejni 4, 61200 Brno, Czech Republic \\ \{kocmanova, docekalova, lunacek\}@ffom. vutbr.cz
}

\begin{abstract}
This paper describes the application of PROMETHEE-GAIA methodology in a multiple criteria analysis to rank potential environmental investments in mineral-processing companies. The intent of the paper is to identify best technical facilities on the basis of preferential relations between a set of variants. The method of Total Cost Analysis (TCA) was chosen to define the criteria. The economic and environmental costs, as well as the benefits of these technical facilities, were determined by means of this method. PROMETHEE is one of the methods in the Multi Criteria Analysis (MCA) category. The MCA, as the name implies, deals with the evaluation of a number of variants by several criteria. The technical facility was selected by a comparative analysis involving five influential parameters (Investment Costs, Annual Operating Costs, Operating Income, Administrative Costs and Disposal Fees, Economic and Environmental Benefits). As expected, the analysis resulted in a preferential ranking of these technical facilities.
\end{abstract}

Keywords: total cost analysis, multicriteria analysis, PROMETHEE, environmental technology, technical facilities.

\section{Introduction}

Decision-making is one of the most important activities in managing a private company, although decisions must likewise be made in public administration and in selfgoverning entities. The ability to make a quick and correct decision is the key to success in any field on any level, be it in business circles, in a national arena, or on an international scale. Decisions are made about financial strategies, investment projects, public government contracts, and a multitude of other endeavors. Public tenders, even though governed by law, would have much fewer problems in defending the outcome if they employed a multiple criteria approach. The impact of these decisions on the entire society should be thoroughly scrutinized. Rather than relying on purely economic considerations, or a subjective judgment, it is necessary to incorporate some additional criteria. This is particularly true when awarding public contracts, for example when trying to choose the right environmental investment, ecological innovation

J. Hřebíček et al. (Eds.): ISESS 2013, IFIP AICT 413, pp. 44-53, 2013.

(C) IFIP International Federation for Information Processing 2013 
or technology, it is necessary to consider also the environmental and the social aspects, along with the economic criteria.

A multi criteria variant analysis represents a valuable tool in reaching rational decisions about environmental investments in the light of multiple criteria and conditions of risks and uncertainty. In a variant evaluation by multiple criteria, it is recommended to use more than one method to verify the sensitivity of the preferential order of variants depending on the method used. If the task is to select an optimal environmental investment, it is necessary to take into account all costs associated with the investment inclusive of the economic, environmental, and social benefits. A good method for this kind of evaluation of environmental investments is Total Cost Analysis (TCA), which selects the optimal environmental investment by means of multiple criteria analysis.

The intent of this paper is to select the optimal environmental investment (technical facility) for the production of cement clinkers, glass, basalt, and ceramic products in companies processing minerals, using the methods of Total Cost Analysis (TCA) and Preference Ranking Organization for Enrichment Evaluation (PROMETHEE).

\section{Theoretical Approach}

The 1990s witnessed an emerging trend in the Czech Republic of investing heavily in environmental protection. Per Czech Statistical Office, CZK 83.3 billion was spent on in 2011 to protect the environment, or about $2.2 \%$ of the GDP. The environmental investments jumped $10 \%$ from the previous year, to CZK 24.8 billion. When environmental investments are pondered, methodological nuances may be crucial. These investments may be inspired by administrative actions, voluntary standards (ecolabeling), stricter product requirements or increasing environmental costs. They are usually accompanied by lack of information about cost-effective solutions. To evaluate an investment, we should know, first of all, if the project is even realistic, and, if so, which of the proposed alternatives is the best. Environmental investments must take into account the non-financial aspects as well, such as the impact on the quality of air, climate, water (surface and underground), soil, etc. The evaluation of an investment (technical equipment) in pursuit of environmental objectives lends itself to multiple criteria-based decision making methods, because these projects tend to be complex and multifaceted [13]. The proposed methods guarantee the inclusion of all relevant data [14]. The goal of such evaluation is done primarily to identify the best option and to rank all options from best to worst. The best variant is usually a compromise [18].

For the purposes of making decisions with multiple criteria, the tasks can be itemized in various ways according to different authors. A breakdown is possible according to the task-solving goal and the information associated with it [2]. Authors Fiala, Jablonský and Maňas [8] describe a division based on the manner of defining the set of acceptable variants. Fotr, Dědina and Hrůzová [9] introduce other types of itemization: by the structure of the problem to be resolved, by the information about the states of the world and the consequences of variants, by the nature of the decision subject viewed as a time factor or the level of control. Finally, Triantaphyllou [18] emphasizes the division mainly by the type of input data. 


\section{$3 \quad$ Methodology}

Arriving to decisions about environmental investments through multiple criteria analysis involves several steps, from formulating the possible versions of a decision to actually adopting it. The objective of the multi criteria variant evaluation is, in most cases, a selection of the optimal (compromise) variant and creating a platform for complex decision-making processes typical for environmental investments. The multi criteria analysis is essentially a mathematical model, the application of which should lead to a selection of the optimal variant from a group of variants feasible in a given situation. Optimal variants are expressed by means of a set of criteria that serve to select the optimal variant. Choosing the right criteria is an important step towards an objective assessment of all variants, and so is the determination how much weight should be given to each criterion in accordance with its importance.

A decision to proceed with a certain environmental investment should consider the requirements of Best Available Techniques (BAT). At the EU level, BAT for selected industrial and agricultural activities are defined and quantified in Best Available Techniques Reference Documents (BREF).

From the financial perspective, environmental investments may be evaluated by identifying all direct and indirect costs, the economic and environmental benefits, and applying a multiple criteria analyzing method like TCA or PROMETHEE. The latter is applicable to a variety of decision problems in diverse fields [1]. PROMETHEE belongs (together with ELECTRE) to a group of outranking methods [17] and it is based on pairwise comparisons [10]. This method was presented for the first time by Jean-Pierre Brans in 1982, see e.g. [4-6]. Together with its descriptive complement, it is known as the PROMETHEE \& GAIA methods.

\subsection{Total Cost Assessment (TCA) Method}

The TCA method includes all relevant costs and benefits related to an environmental investment with the exception of social costs, or externalities [12].This method was developed in an organization named Tellus Institute in Boston. It has been described in foreign literature and modified in various ways [7], [11-12]. The costs are classified as direct, indirect, conditional, and difficult-to-quantify. The most important part of the cost analysis is the necessity to determine all inputs and outputs, to identify all relevant costs and benefits resulting from the environmental investment expressed in monetary units or described qualitatively. The difficulty of itemizing the different types of costs, an essential input in TCA, depends on the probability of their occurrence in the future. The final decision needs to consider all potential factors that may affect the overall effectiveness of a given environmental investments and define their mutual relations. It is therefore imperative to assess both the quantitative and the qualitative criteria. 


\subsection{PROMETHEE Method I, II}

The PROMETHEE-GAIA method is a multicriteria decision method developed by $\mathbf{J}$. P. Brans and B. Mareschal [4-5], [15]. The PROMETHEE-type methods are based on a paired comparison of variants, progressively in terms of all the criteria. The result of this comparison is an expression of preferential intensity between the pairs of variants evaluated with regard to all criteria.

$$
P\left(a_{i}, a_{j}\right)=P\left\lfloor f\left(a_{i}\right)-f\left(a_{j}\right)\right\rfloor=P(d), P(d) \in(0,1)
$$

A higher $P(d)$ value indicates a higher degree of preference of the variant ai over the variant aj. A double-sided preference is described by function $H(d) \in<-1,1>$, defined as:

$$
H(d)=\left[\begin{array}{l}
P\left(a_{i}, a_{j}, d \geq 0\right. \\
P\left(a_{i}, a_{j}, d \leq 0\right.
\end{array}\right]
$$

PROMETHEE recognizes six types of simple functions to express the preferential strength, the so-called generalized criteria, where the parameter $q$ always signifies the breadth of the preferential area and the significance of the parameter $p$ varies with the type of criteria. The calculation consists in selecting an appropriate generalized criterion $a$ for each criterion, and calculating the values of preferential functions for each criterion $a$ of all pairs of variants:

$$
P\left(a_{i}, a_{j}\right), h=1,2, \ldots k, i, j=1,2, \ldots p
$$

Also calculated is a multi-objective preferential index $\pi\left(a_{i}, a_{j}\right) \in\langle 0,1\rangle$, which measures the preferential strength of variant $a_{i}$ over variant $a_{j}$ for all criteria:

$$
\pi\left(a_{i}, a_{j}\right)=\sum_{h=1}^{k} v_{h} P_{h}\left(a_{i}, a_{j}\right)
$$

The outflow of $F^{\prime}\left(a_{i}\right)$ and inflow $F^{\prime}\left(a_{j}\right)$ for all variants is determined as:

$$
\begin{aligned}
& F^{\prime}\left(a_{i}\right)=\sum_{a_{j} \in A} \pi\left(a_{i}, a_{j}\right) \\
& F^{\prime}\left(a_{i}\right)=\sum_{a_{j} \in A} \pi\left(a_{j}, a_{i}\right)
\end{aligned}
$$

This is followed by an evaluation by PROMETHEE I, and possibly by PROMETHEE II, which works with net flows.

$$
F\left(a_{i}\right)=F^{+}\left(a_{i}\right)-F^{-}\left(a_{i}\right)
$$




\subsection{GAIA Method}

The method called Geometrical Analysis for Interactive Aid (GAIA) can be described as a graphic resource for analyzing MCA tasks in continuation of the PROMETHEE category of methods. GAIA method is based on the assumption that each variant aris not characterized by criteria values, but by the so called vector of mono-criteria flows $S_{i}\left(a_{r}\right), i=1,2, \ldots, k$, which are defined as follows:

$$
S_{i}\left(a_{r}\right)=\frac{1}{p-1} \sum_{s=1}^{p}\left[p_{i}\left(a_{r}, a_{s}\right)-p_{i}\left(a_{s}, a_{r}\right)\right]
$$

Each variant can therefore be represented in a k-dimensional vector space by an $R^{k}$ vector

$$
q_{r}=\left[\left(S_{1}\left(a_{r}\right), S_{2}\left(a_{r}\right), \ldots \ldots \ldots \ldots, S_{k}\left(a_{r}\right)\right]\right.
$$

If the number of criteria is $\mathrm{k}=2$, which is not a typical situation, then all variants can be displayed in one plane. Otherwise, the representation must be in a space of a higher dimension. The model for selecting optimal environmental investments for mineral processing companies was processed by Visual PROMETHEE Academic Edition 2013 software (http://www.promethee-gaia.net/index.html).

\section{$4 \quad$ Results and Discussion}

The multiple criteria analysis serves to select the optimal environmental investment for companies processing minerals, taking into account the economic and environmental parameters of the equipment. The resultant ranking provides the rationale for a decision whether the environmental investment should be implemented using public funds. In this paper, the most effective drier was chosen among the eight available and pointed with $a_{i}$ on the basis of six criteria pointed with $f_{j}$. The multi criteria decision problem will be formulated as follows: $\max \left\{\left(f_{l}(a), \ldots f_{k}(a)\right) \mid a \in A\right\}, A=\left\{a_{1}, \ldots\right.$, $\left.a_{n}\right\}$ is a finite set of variants, $\left\{f_{l, \ldots,} f_{k}\right\}$ is a set of evaluation criteria. A methodical solution in selecting the optimal environmental investment is based on the TCA method which involved six established criteria:

- $\mathrm{f}_{1}$ - Investment expenditure, CZK

- $\mathrm{f}_{2}$ - Annual operating costs, $\mathrm{CZK}$

- $\mathrm{f}_{3}$ - Operating income, CZK

- $\mathrm{f}_{4}$ - Administrative cost and disposal fees, CZK

- $\mathrm{f}_{5}$ - Economic benefits, CZK

- $\mathrm{f}_{6}$ - Environmental benefits, CZK

The TCA evaluation method encompasses all relevant costs and benefits from the company's viewpoint, but it does not include the social costs, i.e. the externalities (Kennedy, 1998). The next step was the application of the PROMETHEE multi criteria decision method. The model for the evaluation of future environmental 
investments contains an expert estimate of the set criteria, expressed in the Czech currency (CZK), see Tables 1-4 below.

Table 1. Environmental investment rated by given criteria - costs and income

\begin{tabular}{|c|c|c|c|c|}
\hline \multirow[b]{2}{*}{ Environmental investment } & \multicolumn{2}{|c|}{ Investment Cost } & \multirow{2}{*}{$\begin{array}{c}\text { Operational } \\
\text { cost }\end{array}$} & \multirow{2}{*}{$\begin{array}{l}\text { Operational } \\
\text { income }\end{array}$} \\
\hline & $\begin{array}{l}\text { Life ex- } \\
\text { pectancy }\end{array}$ & $\begin{array}{l}\text { Equipment } \\
\text { cost }\end{array}$ & & \\
\hline Unit & Years & CZK & $\mathrm{CZK} /$ year & CZK/year \\
\hline & Max & Min & Min & Max \\
\hline Instalation of wet gas cleaner & 20 & $5,000,000$ & 100,000 & 0 \\
\hline Replacement of burner & 10 & $1,000,000$ & 20,000 & 100,000 \\
\hline $\begin{array}{l}\text { Replacement of dry electros- } \\
\text { tatic filters }\end{array}$ & 20 & $10,000,000$ & 50,000 & 15,000 \\
\hline Replacement of hose filters & 20 & $40,000,000$ & 10,0000 & 0 \\
\hline $\begin{array}{l}\text { Replacement of exhaust } \\
\text { filters }\end{array}$ & 20 & $250,000,000$ & 30,000 & 0 \\
\hline Replacement of burner & 10 & $35,000,000$ & 50,000 & 100,000 \\
\hline Electrostatic separator & 15 & $6,000,000$ & 50,000 & 0 \\
\hline $\begin{array}{l}\text { Replacement of adsorbers } \\
\text { (cascade\&hose filters, elec- } \\
\text { trostaticseparators) }\end{array}$ & 15 & $10,000,000$ & 40,000 & 0 \\
\hline
\end{tabular}

Table 2. Environmental investment rated by given criteria - administrative costs and fees

\begin{tabular}{l|ccc}
\hline \multirow{2}{*}{ Environmental investment } & \multicolumn{3}{|c}{ One-time administrative costs and fees } \\
\cline { 2 - 4 } Unit & Permit & Documentation & Reporting duty \\
& CZK & CZK & CZK \\
Installation of wet gas cleaner & 30,000 & 20,000 & 30,000 \\
Replacement of burner & 30,000 & 10,000 & 30,000 \\
Replacement of dry electrostatic filters & 30,000 & 15,000 & 30,000 \\
Replacement of hose filters & 30,000 & 50,000 & 30,000 \\
Replacement of exhaust filters & 30,000 & 10,000 & 30,000 \\
Replacement of burner & 30,000 & 15,000 & 30,000 \\
Electrostatic separator & 30,000 & 15,000 & 30,000 \\
Replacement of absorbers (cascade\&hose & 30,000 & 15,000 & 30,000 \\
filters, electrostaticseparators) & \multicolumn{3}{|c}{} \\
\hline
\end{tabular}


Table 3. Environmental investment rated by given criteria - economic benefits

\begin{tabular}{l|cc}
\hline \multirow{2}{*}{$\begin{array}{l}\text { Environmental investment } \\
\text { Unit }\end{array}$} & \multicolumn{2}{|c}{ Economic benefit } \\
\cline { 2 - 3 } & $\begin{array}{c}\text { Better image } \\
\text { CZK/year }\end{array}$ & $\begin{array}{c}\text { Productivity improvement } \\
\text { CZK/year }\end{array}$ \\
Installation of wet gas cleaner & 50,000 & Max \\
Replacement of burner & 50,000 & 0 \\
Replacement of dry electrostatic filters & 50,000 & 30,000 \\
Replacement of hose filters & 300,000 & 0 \\
Replacement of exhaust filters & 150,000 & 0 \\
Replacement of burner & 150,000 & 0 \\
Electrostatic separator & 150,000 & 0 \\
Replacement of adsorbers (cascade\&hose & 150,000 & 0 \\
filters, electrostaticseparators) & & 000 \\
\hline
\end{tabular}

Table 4. Environmental investment rated by given criteria - environmental benefits

\begin{tabular}{l|ccc}
\hline \multirow{2}{*}{\begin{tabular}{l} 
Environmental investment \\
\cline { 2 - 4 } Unit
\end{tabular}} & $\begin{array}{c}\text { Impact on air } \\
\text { and climate } \\
\text { CZK/year }\end{array}$ & $\begin{array}{c}\text { Impact on soil } \\
\text { CZK/year } \\
\text { Max }\end{array}$ & $\begin{array}{c}\text { Impact on } \\
\text { ecological stability } \\
\text { CZK/year }\end{array}$ \\
Instalation of wet gas clean- & 0 & 10,000 & 50,000 \\
er & 10,000 & 0 & 0 \\
Replacement of burner & 10,000 & 10,000 & 50,000 \\
$\begin{array}{l}\text { Replacement of dry electros- } \\
\text { tatic filters }\end{array}$ & 20,000 & 0 & $5,000,000$ \\
Replacement of hose filters & 20,000 & 0 & $5,000,000$ \\
$\begin{array}{l}\text { Replacement of exhaust } \\
\text { filters }\end{array}$ & & & 500,000 \\
Replacement of burner & 60,000 & 0 & 500,000 \\
$\begin{array}{l}\text { Electrostatic separator } \\
\text { Replacement of adsorbers } \\
\text { (cascade\&hose filters, elec- }\end{array}$ & 10,000 & 0 & 500,000 \\
trostaticseparators) & 15,000 & & \\
\hline
\end{tabular}

The same weight (0.1667) is assigned for each criterion. The PROMETHEE II provides complete ranking, see Fig. 1. It is based on a balance of two preferential flow. The upper half of the scale (green) corresponds to a positive Phi score and the bottom half (in red) to negative score. Investments 2 (Replacement of burner) is above all investments while investments 1 (Instalation of wet gas cleaner) and 4 (Replacement of hose filters) are the worst. 


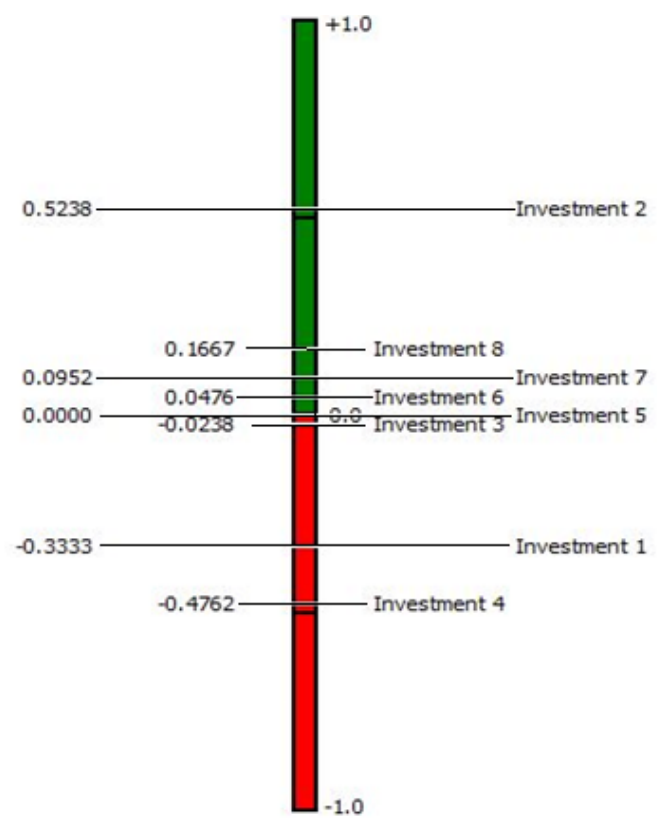

Fig. 1. The PROMETHEE II complete ranking

In the Table 5 PROMETHEE Flow Table we can see Phi, Phi+, Phi- score. Investments are ordered by PROMETHEE II complete ranking. The positive flow expresses how much an alternative is dominating the other ones, and the negative flow how much it is dominated by the other ones.

Table 5. PROMETHEE Flow Table

\begin{tabular}{c|rrr}
\hline Environmental investments & Phi & Phi+ & Phi- \\
\hline Investment 2 & 0.5238 & 0.7381 & 0.2143 \\
Investment 8 & 0.1667 & 0.4762 & 0.3095 \\
Investment 7 & 0.0952 & 0.4286 & 0.3333 \\
Investment 6 & 0.0476 & 0.4524 & 0.4048 \\
Investment 5 & 0.0000 & 0.4286 & 0.4286 \\
Investment 3 & -0.0238 & 0.4048 & 0.4286 \\
Investment 1 & -0.3333 & 0.2619 & 0.5952 \\
Investment 4 & -0.4762 & 0.1905 & 0.6667 \\
\hline
\end{tabular}

It is clear, that PROMETHEE II is influenced by weights assigned to criteria. Walking Weight allows to adjust the weights and to observe the resulting changes. If we modify weights of Annual operating costs at $21 \%$ and Administrative cost and disposal fees at $21 \%$, than other weights will change to $14 \%$. Investment 2 still dominates the others and investment 5 (Replacement of exhaust filters) has positive Phi score. Fig. 2 shows the PROMETHEE Network which presents PROMETHEE I partial ranking. Investments are nodes and preferences are indicated by arrows. 
Investment 2 is significantly preferred to other investments. Investments 6 (Replacement of burner), 5 (Replacement of exhaust filters) and 3 (Replacement of dry electrostatic filters) are incomparable and very close to each other.

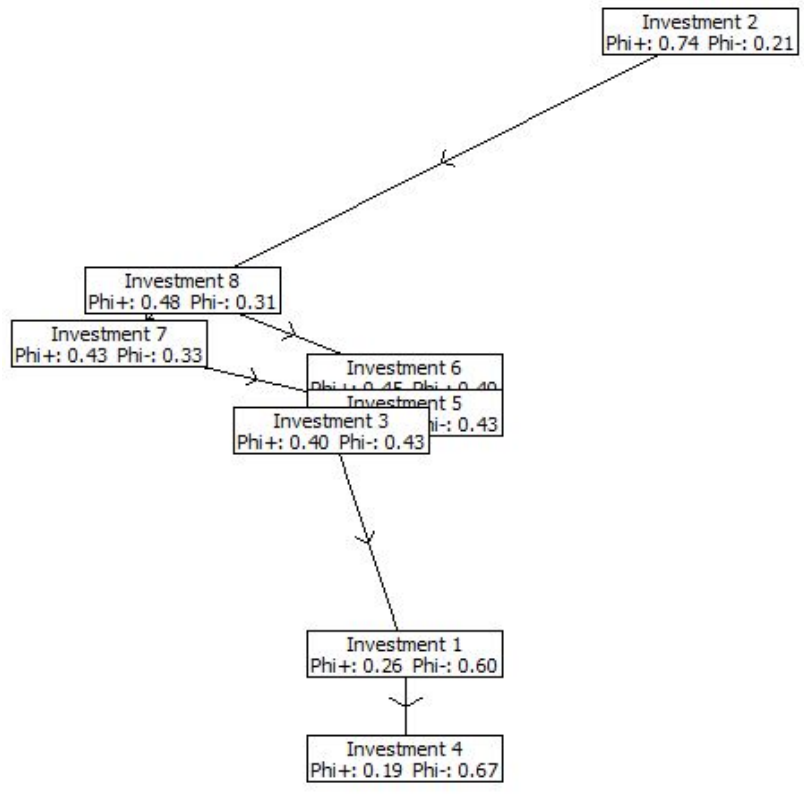

Fig. 2. PROMETHEE Network

\section{Conclusions}

When evaluating environmental investments (e.g. technical facilities) it is very important to identify and consider all types of costs, potential cost savings and other benefits associated with the investment, because this is the only way to properly evaluate the effectiveness of investments. The method of Total Cost Analysis was chosen to define the criteria - investments costs, operational costs, operational income, administrative costs and fees, economic benefits (better image and productivity improvement), environmental benefits (impact on air and climate, impact on soil and impact on ecological stability). After collecting and analyzing data follows an evaluation of investment efficiency. To evaluate 8 technical facilities by 6 criteria, the PROMETHEE as one of the methods in the multi criteria analysis was employed. The result of the method proposed in this paper is the final ranking of investments on the basis of which a qualified decision can be made.

Acknowledgements. This paper is supported by The Czech Science Foundation. Name of the Project: Construction of Methods for Multifactor Assessment of Company Complex Performance in Selected Sectors. Reg. Nr. P403/11/2085. 


\section{References}

1. Behzadian, M., Kazemzadeh, R.B., Albadvi, A., Aghdasi, M.: PROMETHEE: A comprehensive literature review on methodologies and applications. European Journal of Operational Research 200, 198-215 (2010)

2. Brožová, H., Houška, M., Šubrt, T.: Modely pro vícekriteriální rozhodování. CREDIT, Praha (2003)

3. Brans, J.P.: L'ingénierie de la décision: élaboration d'instruments d'aide à la décision. La méthode PROMETHEE. Presses de l'Université Laval (1982)

4. Brans, J.P., Mareschal, B.: Promethee V: MCDM problems with additional segmentation constraints. INFOR 30, 85-96 (1992)

5. Brans, J.P., Mareschal, B.: PROMETHEE methods. In: Multiple Criteria Decision Analysis: State of the Art Surveys, pp. 163-186. Springer, New York (2005)

6. Brans, J.P., Vincke, P.: A preference ranking organisation method: The PROMETHEE method for MCDM. Management Science 31, 647-656 (1985)

7. Cokins, G.: Aktivity-Based Cost Management. An Executive's Guide. John Wiley \& Sons. Inc., New York (2001)

8. Fiala, P., Jablonský, J., Maňas, M.: Vícekriteriální rozhodování. VŠE, Praha (1994)

9. Fotr, J., Dědina, J., Hrůzová, H.: Manažerské rozhodování. EKOPRESS, Praha (2003)

10. Greco, S. (ed.): Multiple criteria decision analysis: state of the art surveys, vol. 78. Springer (2004)

11. Kennedy, M.L.: The Cost of Changing: Total Cost Assessment of Solvent Alternatives. The Massachusetts Toxic Use Reduction Institute. University of Massachusetts Lowel (1994)

12. Kennedy, M.L.: Total Cost Assessment for Environmental Engineers and Managers. John Wiley \& Sons. Inc., New York (1998)

13. Kiker, G.A., Bridges, T.S., Varghese, A., Seager, T.P., Linkov, I.: Application of multicriteria decision analysis in environmental decision making. Integrated Environmental Assessment and Management 2, 95-108 (2005)

14. Lahdelma, R., Salminen, P., Hokkanen, J.: Using multicriteria methods in environmental planning and management. Environmental Management 26, 595-605 (2000)

15. Macharis, C., Springael, J., De Brucher, K., Verbeke, A.: Promethee and AHP: the design of operational synergies in multicriteria analysis. Strengthening PROMETHEE with ideas of AHP. European Journal of Operational Research 153, 307-317 (2004)

16. Mareschal, B., Brans, J.P.: Geometrical representations for MCDA. The GAIA module. European Journal of Operational Research 34, 69-77 (1988)

17. Munier, N.: A Strategy for Using Multicriteria Analysis in Decision-making: A Guide for Simple and Complex Environmental Projects. Springer, Dordrecht (2011)

18. Triantaphyllou, E.: Multi-criteria decision making methods, pp. 5-21. Springer US (2000) 